Article

\title{
Local Item Dependence on the Vocabulary Levels Test Revisited
}

\author{
Tadamitsu Kamimoto \\ Kumamoto Gakuen University \\ doi: http://dx.doi.org/10.7820/vli.v03.2.kamimoto
}

\begin{abstract}
The purpose of this study was to address the question of local item dependence (LID) on the Vocabulary Levels Test (VLT). The test format adopts a matching format consisting of six words and three definitions. A review of the literature suggested that items presented in such a format cannot be considered independent. However, Schmitt, Schmitt, and Clapham reported that according to Rasch analysis, most of the items performed independently. The present study examined effects of LID from a non-Rasch approach. A set of three clusters was collapsed into one large cluster of 18 words and 9 definitions on the assumption that such a treatment would make items practically independent. Both the collapsed VLT and the intact VLT were given to 114 Japanese English as a Foreign Language (EFL) students at an interval of one week. Results showed that scores were $15 \%$ higher on the original VLT than on the collapsed form. Furthermore, an LID index based on the correct/wrong response types between the two tests indicated that scores on the original VLT were about $19 \%$ inflated. Implications were drawn and discussed.
\end{abstract}

\section{Background}

Nation's (1990) Vocabulary Levels Test (VLT) and its revised forms (Nation, 2001; Schmitt, 2000; Schmitt, Schmitt, \& Clapham, 2001) are still in use (e.g., Akbarian, 2010; Li \& MacGregor, 2010; Rashidi \& Piran, 2011; Staehr, 2008; Webb, 2007). Validations of the VLT have been carried out by Read (1988), Beglar and Hunt (1999) and Schmitt et al. (2001). They all indicated that the test is a good measurement of vocabulary knowledge. However, there is one issue which has not been adequately addressed: local item dependence (LID). It is assumed that a response to an item should be independent of a response to another item (Hambleton, Swaminathan, \& Roger, 1991; Lee, 2004; Zenisky, Hambleton, \& Sireci, 2002). However, the VLT seems to violate this assumption (e.g., Nation, 2007).

Where does the possible violation of item independence come from? It comes from the test format - the matching format, as shown in Figure 1. This format, interacting with test takers' knowledge of words, is responsible for triggering LID to various degrees. The most serious effect of LID is to increase the chance of guessing correctly (Mochizuki, 1998; Shillaw, 1999; Stewart, \& White, 2011). 


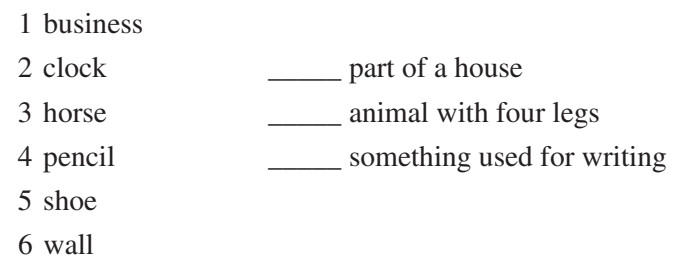

Figure 1. Example of the VLT Format.

In the validation studies, Beglar and Hunt (1999) and Schmitt et al. (2001) found some dependent items on the basis of Rasch analysis. However, they interpreted that most items were not dependent and caused no particular adverse effects to their following analyses. Then, they shifted items to make parallel forms [see Xing \& Fulcher (2007) for criticism]. This paper shall revisit the LID issue and examine it from a non-Rasch approach.

\section{Method}

\subsection{Material}

This study used the original VLT (Nation, 1990). Among the five word levels available, four levels were used. One level consisted of six clusters, each of which had six words and three definitions, as shown in Figure 1. The original test was referred to as "6 3 form" (see Appendix 1). On the basis of this material, an experimental matching format was constructed by collapsing a set of three clusters into one large cluster consisting of 18 words and 9 definitions. This collapsed form was referred to as "18 9 form" (see Appendix 2).

\subsection{Participants and Procedure}

Three groups of EFL Japanese university students took the 189 form first and one week later the 63 form. Due to absence on either of the two occasions, several students were dropped from the analysis, leaving a total of 114 participants.

\section{Results and Discussion}

\subsection{Descriptive Statistics}

Table 1 shows participants' overall performance on the two forms. There are two points to be noted. First, the mean scores for the 63 form were larger across all the four word-frequency levels than the mean scores for the 189 form. Second, as the word-frequency levels became lower, the mean scores for the two forms became smaller but differences in scores gradually increased. Paired $t$-tests show that all the differences were statistically significant at the 0.01 level $(d f=113, t$ values $=$ 9.16 for $2 \mathrm{~K}, r=.65$; 14.90 for $3 \mathrm{~K}, r=.82$; 16.63 for $5 \mathrm{~K}, r=.84$; and 16.75 for AWL (Academic Word List), $r=.84$, two-tailed). 
Table 1. Means and Standard Deviations of Scores for the Two Forms

\begin{tabular}{lrrrrr}
\hline & \multicolumn{2}{c}{ Mean (\%) } & & \multicolumn{2}{c}{ SD (\%) } \\
\cline { 2 - 3 } \cline { 5 - 6 } Word level & \multicolumn{1}{c}{63 form } & \multicolumn{1}{c}{189 form } & Differences (\%) & 63 form & 189 form \\
\hline 2K & $15.96(88.67)$ & $14.52(80.67)$ & $1.44(8.00)$ & $1.66(9.22)$ & $2.29(12.72)$ \\
3K & $13.63(75.72)$ & $10.89(60.50)$ & $2.75(15.22)$ & $2.46(13.67)$ & $2.92(16.22)$ \\
5K & $10.54(58.56)$ & $7.27(40.39)$ & $3.26(18.13)$ & $2.42(13.72)$ & $2.07(11.50)$ \\
AWL & $9.34(51.89)$ & $5.72(31.78)$ & $3.62(20.11)$ & $2.91(16.17)$ & $2.97(16.50)$ \\
Sum $^{\mathrm{a}}$ & $49.47(68.71)$ & $38.40(53.33)$ & $11.07(15.38)$ & $7.39(10.26)$ & $8.49(11.76)$ \\
\hline
\end{tabular}

The maximum score per word level is 18 .

${ }^{\text {a}}$ Figures in this row do not always add up to a sum of four figures in each column due to rounding.

\subsection{Item Facility}

Item facility (IF) indices were employed to identify LID items. We subtracted IF values of items for the 189 form from corresponding IF values of the same items for the 63 form. Results showed that the IF differences ranged from -0.009 to +0.421 , with a mean of 0.154 (see Appendix 3 for details). All IF differences fell above zero except one item, ${ }^{1}$ and three items had the same score. With regard to the remaining 68 items, participants performed better on the 63 form than on the 189 form.

Figure 2 is a graphical representation of the entire IF data. Each vertical line has two IF values at its ends; a triangle indicates an IF value for the 63 form and a cross indicates an IF value for the 189 form. Its length represents how widely the IF values of the same item are different. Although several items with no or very short length were found here and there, most of the items had various degrees of length. In short, the number of items with some length outnumbers by far the number of items with no or very short length, suggesting strongly that the 63 form inflated the scores of most items.

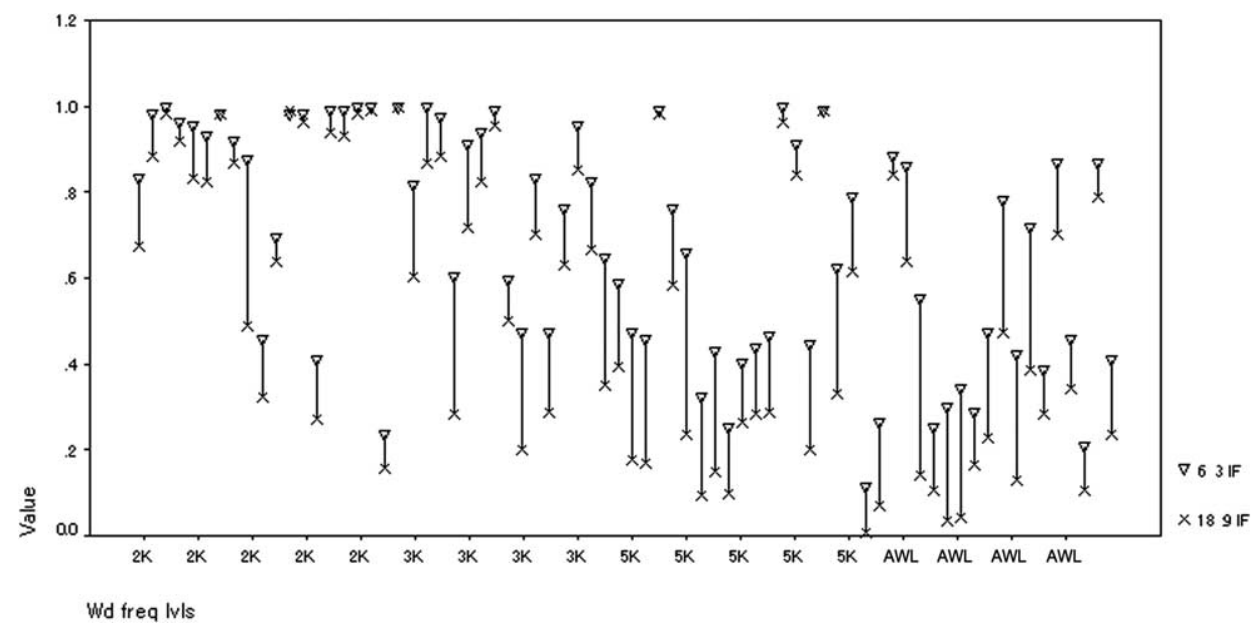

Figure 2. Drop-line Plot of IF Values between the Two Forms. 
Table 2. A Frequency Table of Items by Word Levels and IF Differences

\begin{tabular}{lrrrrc}
\hline & $2 \mathrm{~K}$ & $3 \mathrm{~K}$ & $5 \mathrm{~K}$ & $\mathrm{AWL}$ & Total $(\%)$ \\
\hline IF diff ranges & & & & & \\
$0.50 \leqq \sim<0.60$ & & & & & \\
$0.40 \leqq \sim<0.50$ & & & 1 & 1 & $2(2.78)$ \\
$0.30 \leqq \sim<0.40$ & 1 & 1 & & 2 & $4(5.56)$ \\
$0.20 \leqq \sim<0.30$ & & 3 & 6 & 5 & $14(19.44)$ \\
$0.10 \leqq \sim<0.20$ & 5 & 9 & 7 & 8 & $29(38.89)$ \\
$0.00 \leqq \sim<0.10$ & 11 & 5 & 4 & 2 & $22(26.39)$ \\
$-0.10 \leqq \sim<0.00$ & 1 & & & & $1(4.17)$ \\
Total & 18 & 18 & 18 & 18 & $72(100)$ \\
\hline
\end{tabular}

In the hope of sketching out the general features of the data on item difficulty, the frequency counts were tabulated according to both the IF difference range and the word levels in Table 2. For identification of LID items, two cut-off points can be adopted, depending on the level of severity. If an IF difference of 0.10 is adopted on an assumption that measurement error can happen within an IF difference range of less than 0.10, LID items account for $49(68.06 \%)$ of 72 items. They include $62 \mathrm{~K}$ items, $133 \mathrm{~K}$ items, $145 \mathrm{~K}$ items and $16 \mathrm{AWL}$ items. If a lenient criterion of 0.20 is adopted, LID items account for $20(27.78 \%)$ of all the items: one $2 \mathrm{~K}$ item, four $3 \mathrm{~K}$ items, seven $5 \mathrm{~K}$ items and eight AWL items. It should also be noted that the number of the LID items increased as word difficulty increased in the order of word frequency. In other words, it appears that LID tends to become more marked as words become less frequent.

\subsection{LID Items}

IF indices are a handy but rough measure for the identification of LID items because IF values on the 63 form represent the end product of a series of test-taking behaviours within a cluster. For more accurate identification, it is preferable to see whether the participants' responses are consistent or not between the 63 and 189 forms. Figure 3 illustrates four possible response types on items between the two forms. When participants matched an item correctly to a definition

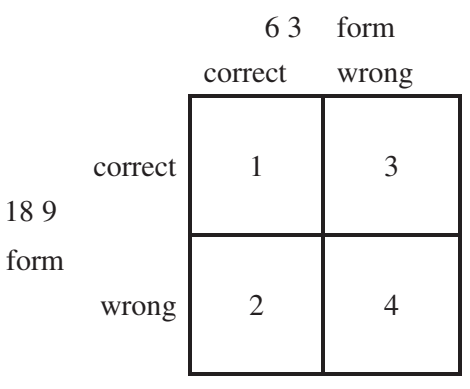

Figure 3. A Taxonomy of Response Types between the Two Forms. 
on both the 63 and 189 forms, their response can be considered as LID-free. Participants would answer right irrespective of other words within a cluster. This response type corresponds to the first cell. On the other hand, if a response was correct on the 63 form but wrong on the 189 form, it suggests that the participants did not actually know an item and they unduly gained a score on the 63 format. This response type is where guessing effects by LID are found. The second cell is the case in point. The opposite case where a response is correct on the 189 form but wrong on the 63 form is expected to be rare. This corresponds to the third cell. Finally, a wrong response on both forms suggests that the participants did not know the item. This is a response type of the fourth cell. Our chief concern is with response Type 2 .

Table 3 shows frequencies of the following three types of data: (1) the number correct on the two forms, (2) an overlap between them corresponding to the first cell in Figure 3 and (3) deviations on the 63 and 189 forms from an overlap corresponding, respectively, to the second and third cells. Items are displayed in the order of appearance on the 63 form. A glance at the table indicates that the frequency for response Type 2 ranged from 0 to $53(46.49 \%)$, indicating that guessing effects of LID varied considerably from one item to another.

This frequency table is also very useful in comprehending how items in a cluster affect one another. As an illustrative example, let us take up the case of "spoil" from the $2 \mathrm{~K}$ word level, which had the second highest LID index of 46 $(40.35 \%)$ among all the items. As the table shows, 56 participants were correct on the 189 form, and one week later the number correct for the item on the 63 form increased to 100 . How did such a large increase take place? The other two target items with which "spoil" shared the same cluster were "invite" and "hide". They had an overlap of 110 and 99, respectively, and the LID indices for them were 2 and 6. In short, these two items were extremely easy when compared with "spoil". After matching them correctly to definitions, the participants apparently tackled with "spoil". In the end, it appears that 46 participants ended up gaining a score, while the remaining number of the participants chose one of the three distractors of "blame," "hit" and "pour" which were relatively easy.

Table 4, summing up the data above, displays descriptive statistics of the guessing rates according to word frequency level. Means ranged from $9.89 \%$ for the $2 \mathrm{~K}$ word level to $24.61 \%$ for the AWL level with a mean of $18.84 \%$. The guessing rates increased as word frequency decreased, suggesting that the less frequent the word levels may be, the more dependent items tend to be. It is interesting to note that the guessing rates are higher than the corresponding IF differences shown in Table 1. This evidence, adequately supporting Stewart \& White (2011), showed that successful guessing may be more prevalent than their theoretical estimation of guessing even when items are less frequent.

\section{Conclusion}

These findings have shown that the original matching format of the VLT has a mean guessing rate of $18.84 \%$. This rate may vary according to test takers' lexical proficiency and the number of word levels involved. It seems reasonable to 
Table 3. A Frequency Table of Response Types

\begin{tabular}{|c|c|c|c|c|c|c|}
\hline \multirow[b]{3}{*}{ Word ID } & \multirow[b]{3}{*}{ Item } & \multirow{2}{*}{\multicolumn{2}{|c|}{$\begin{array}{c}\text { Number } \\
\text { correct }\end{array}$}} & \multicolumn{3}{|c|}{ Response } \\
\hline & & & & \multirow{2}{*}{$\begin{array}{l}\text { Type } 1 \\
\text { Overlap }\end{array}$} & \multirow{2}{*}{$\begin{array}{c}\text { Type } 2 \\
63(\%)\end{array}$} & \multirow{2}{*}{$\begin{array}{r}\text { Type } 3 \\
189(\%)\end{array}$} \\
\hline & & 63 & 189 & & & \\
\hline $2 \mathrm{~K} 01$ & original & 95 & 77 & 76 & 19 (16.67) & $1(0.88)$ \\
\hline $2 \mathrm{~K} 02$ & private & 112 & 101 & 100 & $12(10.53)$ & $1(0.88)$ \\
\hline $2 \mathrm{~K} 03$ & total & 114 & 112 & 112 & $2(1.75)$ & $0(0.00)$ \\
\hline $2 \mathrm{~K} 04$ & manufacture & 110 & 105 & 104 & $6(5.26)$ & $1(0.88)$ \\
\hline $2 \mathrm{~K} 05$ & elect & 109 & 95 & 91 & $18(15.79)$ & $4(3.51)$ \\
\hline 2K06 & melt & 106 & 94 & 93 & $13(11.40)$ & $1(0.88)$ \\
\hline 2K07 & invite & 112 & 112 & 110 & $2(1.75)$ & $2(1.75)$ \\
\hline $2 \mathrm{~K} 08$ & hide & 105 & 99 & 99 & $6(5.26)$ & $0(0.00)$ \\
\hline 2K09 & spoil & 100 & 56 & 54 & $46(40.35)$ & $2(1.75)$ \\
\hline $2 \mathrm{~K} 10$ & roar & 52 & 37 & 27 & 25 (21.93) & $10(8.77)$ \\
\hline 2K11 & debt & 79 & 73 & 63 & $16(14.04)$ & $10(8.77)$ \\
\hline 2K12 & pride & 112 & 113 & 111 & $1(0.88)$ & $2(1.75)$ \\
\hline $2 \mathrm{~K} 13$ & temperature & 112 & 110 & 109 & $3(2.63)$ & $1(0.88)$ \\
\hline 2K14 & flesh & 47 & 31 & 30 & $17(14.91)$ & $1(0.88)$ \\
\hline 2K15 & salary & 113 & 107 & 107 & $6(5.26)$ & $0(0.00)$ \\
\hline $2 \mathrm{~K} 16$ & sport & 113 & 106 & 105 & $8(7.02)$ & $1(0.88)$ \\
\hline 2K17 & victory & 114 & 112 & 112 & $2(1.75)$ & $0(0.00)$ \\
\hline 2K18 & birth & 114 & 113 & 113 & $1(0.88)$ & $0(0.00)$ \\
\hline $3 \mathrm{~K} 01$ & herd & 27 & 18 & 13 & $14(12.28)$ & $5(4.39)$ \\
\hline $3 \mathrm{~K} 02$ & angel & 114 & 114 & 114 & $0(0.00)$ & $0(0.00)$ \\
\hline 3К03 & administration & 93 & 69 & 59 & $34(29.83)$ & $10(8.77)$ \\
\hline 3К04 & bench & 114 & 99 & 99 & $15(13.16)$ & $0(0.00)$ \\
\hline 3К05 & charity & 111 & 101 & 101 & $10(8.77)$ & $0(0.00)$ \\
\hline 3K06 & province & 69 & 32 & 29 & 40 (35.09) & $3(2.63)$ \\
\hline 3К07 & echo & 104 & 82 & 78 & $26(22.81)$ & $4(3.51)$ \\
\hline 3K08 & darling & 107 & 94 & 93 & $14(12.28)$ & $1(0.88)$ \\
\hline 3К09 & slice & 113 & 109 & 109 & $4(3.51)$ & $0(0.00)$ \\
\hline $3 \mathrm{~K} 10$ & palm & 68 & 57 & 46 & $22(19.30)$ & $11(9.65)$ \\
\hline 3K11 & scheme & 54 & 23 & 22 & $32(28.07)$ & $1(0.88)$ \\
\hline 3K12 & thrill & 95 & 80 & 78 & 17 (14.91) & $2(1.75)$ \\
\hline $3 \mathrm{~K} 13$ & illustrate & 54 & 33 & 23 & 31 (27.19) & $10(8.77)$ \\
\hline 3K14 & encounter & 87 & 72 & 66 & $21(18.42)$ & $6(5.26)$ \\
\hline 3K15 & toss & 109 & 97 & 96 & $13(11.40)$ & $1(0.88)$ \\
\hline 3K16 & annual & 94 & 76 & 75 & $19(16.67)$ & $1(0.88)$ \\
\hline 3K17 & savage & 74 & 40 & 33 & 41 (35.97) & $7(6.14)$ \\
\hline $3 \mathrm{~K} 18$ & definite & 67 & 45 & 37 & $30(26.32)$ & $8(7.02)$ \\
\hline $5 K 01$ & phase & 54 & 20 & 14 & 40 (35.09) & $6(5.26)$ \\
\hline $5 \mathrm{~K} 02$ & mess & 52 & 19 & 16 & $36(31.58)$ & $3(2.63)$ \\
\hline $5 \mathrm{~K} 03$ & apron & 113 & 112 & 111 & $2(1.75)$ & $1(0.88)$ \\
\hline $5 K 04$ & trumpet & 87 & 66 & 61 & $26(22.81)$ & $5(4.39)$ \\
\hline $5 K 05$ & stool & 75 & 27 & 22 & $53(46.49)$ & 5 (4.39) \\
\hline $5 K 06$ & sermon & 37 & 11 & 9 & $28(24.56)$ & $2(1.75)$ \\
\hline $5 K 07$ & compliment & 49 & 17 & 13 & $36(31.58)$ & $4(3.51)$ \\
\hline
\end{tabular}


Table 3 (Continued)

\begin{tabular}{|c|c|c|c|c|c|c|}
\hline \multirow[b]{3}{*}{ Word ID } & \multirow[b]{3}{*}{ Item } & \multirow{2}{*}{\multicolumn{2}{|c|}{$\begin{array}{c}\text { Number } \\
\text { correct }\end{array}$}} & \multicolumn{3}{|c|}{ Response } \\
\hline & & & & \multirow{2}{*}{$\begin{array}{l}\text { Type } 1 \\
\text { Overlap }\end{array}$} & \multirow{2}{*}{$\begin{array}{c}\text { Type } 2 \\
63(\%)\end{array}$} & \multirow{2}{*}{$\begin{array}{r}\text { Type } 3 \\
189(\%)\end{array}$} \\
\hline & & 63 & 189 & & & \\
\hline $5 \mathrm{~K} 08$ & apparatus & 29 & 11 & 6 & $23(20.18)$ & $5(4.39)$ \\
\hline $5 K 09$ & revenue & 46 & 30 & 15 & $31(27.19)$ & $15(13.16)$ \\
\hline $5 \mathrm{~K} 10$ & precede & 50 & 32 & 21 & $29(25.44)$ & $11(9.65)$ \\
\hline $5 \mathrm{~K} 11$ & collapse & 53 & 33 & 26 & 27 (23.68) & $7(6.14)$ \\
\hline $5 \mathrm{~K} 12$ & skip & 114 & 110 & 110 & $4(3.51)$ & $0(0.00)$ \\
\hline $5 K 13$ & blend & 104 & 96 & 91 & $13(11.40)$ & $5(4.39)$ \\
\hline $5 K 14$ & devise & 51 & 23 & 16 & $35(30.70)$ & $7(6.14)$ \\
\hline $5 \mathrm{~K} 15$ & hug & 113 & 113 & 113 & $0(0.00)$ & $0(0.00)$ \\
\hline $5 \mathrm{~K} 16$ & gloomy & 71 & 38 & 34 & 37 (32.46) & $4(3.51)$ \\
\hline $5 K 17$ & fragrant & 90 & 70 & 68 & $22(19.30)$ & $2(1.75)$ \\
\hline $5 \mathrm{~K} 18$ & wholesome & 13 & 1 & 0 & $13(11.40)$ & $1(0.88)$ \\
\hline AWL01 & affluence & 30 & 8 & 4 & $26(22.81)$ & $4(3.51)$ \\
\hline AWL02 & episode & 101 & 96 & 89 & $12(10.53)$ & $7(6.14)$ \\
\hline AWL03 & innovation & 96 & 73 & 68 & $28(24.56)$ & $5(4.39)$ \\
\hline AWL04 & deficiency & 63 & 16 & 15 & $48(42.11)$ & $1(0.88)$ \\
\hline AWL05 & prestige & 29 & 12 & 5 & $24(21.05)$ & $7(6.14)$ \\
\hline AWL06 & oscillation & 34 & 4 & 2 & $32(28.07)$ & $2(1.75)$ \\
\hline AWL07 & configuration & 39 & 5 & 2 & 37 (32.46) & $3(2.63)$ \\
\hline AWL08 & discourse & 33 & 19 & 9 & $24(21.05)$ & $10(8.77)$ \\
\hline AWL09 & hypothesis & 54 & 26 & 20 & $34(29.83)$ & $6(5.26)$ \\
\hline AWL10 & supplement & 89 & 54 & 52 & 37 (32.46) & $2(1.75)$ \\
\hline AWL11 & expel & 48 & 15 & 11 & 37 (32.46) & $4(3.51)$ \\
\hline AWL12 & deprive & 82 & 44 & 40 & $42(36.84)$ & $4(3.51)$ \\
\hline AWL13 & restrict & 44 & 32 & 22 & $22(19.30)$ & $10(8.77)$ \\
\hline AWL14 & transform & 99 & 80 & 76 & $23(20.18)$ & 4 (3.51) \\
\hline AWL15 & assume & 52 & 39 & 36 & $16(14.04)$ & $3(2.63)$ \\
\hline AWL16 & indigenous & 24 & 12 & 2 & $22(19.30)$ & $10(8.77)$ \\
\hline AWL17 & minimum & 99 & 90 & 86 & $13(11.40)$ & $4(3.51)$ \\
\hline AWL18 & anonymous & 47 & 27 & 19 & $28(24.56)$ & $8(7.02)$ \\
\hline
\end{tabular}

conclude, however, that this study indicates that items in clusters tend to be more dependent than the previous Rasch-based studies suggested. This may lead us to wonder if they have met the item response theory (IRT) requirement of item independence between responses to any pair of items.

Table 4. Descriptive Statistics of Guessing Rates by Word-frequency Level

\begin{tabular}{lcc}
\hline & Mean (\%) & SD (\%) \\
\hline $2 \mathrm{~K}$ & $11.28(9.89)$ & $11.35(9.96)$ \\
3K & $21.28(18.67)$ & $11.70(10.26)$ \\
5K & $25.28(22.17)$ & $14.26(12.51)$ \\
AWL & $28.06(24.61)$ & $9.85(8.64)$ \\
Four levels & $21.47(18.84)$ & $13.29(11.65)$ \\
\hline
\end{tabular}




\section{Note}

1. The item is "pride" from the $2 \mathrm{~K}$ word frequency level. This was the only item with a minus IF difference from among a total of 72 items. Its value $(-0.009)$ was extremely small and equivalent to one participant. This irregularity may be caused by a participant's carelessness. It can be dismissed as negligible.

\section{References}

Akbarian, I. (2010). The relationship between vocabulary size and depth for ESP/ EAP learners. System, 38, 391-401. doi:10.1016/j.system.2010.06.013

Beglar, D., \& Hunt, A. (1999). Revising and validating the 2000 word level and university word level. Language Testing, 16, 131-162. doi:10.1177/ 026553229901600202

Hambleton, R. K., Swaminathan, H., \& Roger, H. J. (1991). Fundamentals of item response theory (Vol. 2). London, UK: Sage.

Lee, Y.-W. (2004). Examining passage-related local item dependence (LID) and measurement construct using $\mathrm{Q}_{3}$ statistics in an EFL reading comprehension test. Language Testing, 21, 74-100. doi:10.1191/02655322041t260oa

Li, L., \& MacGregor, L. J. (2010). Investigating the receptive vocabulary size of university-level Chinese learners of English: How suitable is the Vocabulary Levels Test? Language and Education, 24, 239-249. doi:10.1080/ 09500781003642478

Mochizuki, M. (1998). Nihonjin Eigo Gakushusha no tameno goi saizu tesuto [A vocabulary size test for Japanese learners of English]. The IRLT (Institute for Research in Language Teaching) Bulletin, 12, 27-53.

Nation, I.S.P. (1990). Teaching and learning vocabulary. Boston, MA: Heinle \& Heinle.

Nation, I.S.P. (2001). Learning vocabulary in another language. Cambridge, UK: Cambridge University Press.

Nation, I.S.P. (2007). Fundamental issues in modelling and assessing vocabulary knowledge. In H. Daller, J. Milton \& J. Treffers-Daller (Eds.), Modelling and assessing vocabulary knowledge (pp. 35-43). Cambridge, UK: Cambridge University Press.

Rashidi, N., \& Piran, M. (2011). The effect of extensive and intensive reading on Iranian EFL learners' vocabulary size and depth. Journal of Language Teaching and Research, 2, 471-482. doi:10.4304/j1tr.2.2.471-482

Read, J. (1988). Measuring the vocabulary knowledge of second language learners. RELC Journal, 19(2), 12-25. doi:10.1177/003368828801900202

Schmitt, N. (2000). Vocabulary in language teaching. Cambridge, UK: Cambridge University Press.

Schmitt, N., Schmitt, D., \& Clapham, C. (2001). Developing and exploring the behaviour of two new versions of the Vocabulary Levels Test. Language Testing, 18, 55-88. doi:10.1177/026553220101800103 
Shillaw, J. (1999). The application of the Rasch model to yes/no Vocabulary Tests (Unpublished Ph.D. thesis). University of Wales Swansea, Swansea, Wales.

Staehr, L. S. (2008). Vocabulary size and the skills of listening, reading and writing. Language Learning Journal, 36, 139-152. doi:10.1080/09571730802389975

Stewart, J., \& White, D. A. (2011). Estimating guessing effects on the Vocabulary Levels Test for differing degrees of word knowledge. TESOL Quarterly, 45, 370-380.

Webb, S. (2007). The effects of repetition on vocabulary knowledge. Applied Linguistics, 28, 46-65. doi:10.1093/applin/am1048

Xing, P., \& Fulcher, G. (2007). Reliability assessment for two versions of Vocabulary Levels Tests. System, 35, 182-191. doi:10.1016/j.system. 2006.12.009

Zenisky, A. L., Hambleton, R. K., \& Sireci, S. G. (2002). Identification and evaluation of local item dependencies in the medical college admissions test. Journal of Educational Measurement, 39, 291-309. doi:10.1111/j.1745-3984. 2002.tb01144.x 


\section{Appendix 1}

\section{Form (Sample)}

3K word frequency level

1 administration

2 angel

— 群れ

3 frost 天使

4 herd 運営

5 fort

6 pond

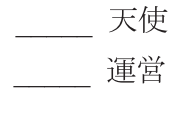

1 bench

2 charity

長椅子

3 mate

慈善

4 jar 地方

5 mirror

6 province

1 marble

2 palm

手のひら

3 ridge 計画

4 scheme わくわくする感じ

5 statue

6 thrill

1 discharge

2 encounter 例証する

3 illustrate 出合う

4 prevail を投げる

5 restore

6 toss

1 coach

2 darling こだま

3 echo 最愛の人

4 interior 薄切り 1 枚

5 opera

6 slice

1 annual

2 previous 年 1 回の

3 mental 野生の

4 concealed はっきりと確定した

5 definite

6 savage 


\section{Appendix 2}

\section{Form (Sample)}

3K word frequency level

$\begin{array}{ll}\text { (A) } & \\ 1 \text { administration } \\ 2 \text { angel } & \\ 3 \text { bench } & \text { 薄切り } 1 \text { 枚 } \\ 4 \text { charity } & \text { 運営 } \\ 5 \text { coach } & \text { こだま } \\ 6 \text { darling } & \text { 最愛の人 } \\ 7 \text { echo } & \text { 慈善 } \\ 8 \text { fort } & \text { 地方 } \\ 9 \text { frost } & \text { 天使 } \\ 10 \text { herd } & \text { 長椅子 } \\ 11 \text { interior } & \text { 群れ } \\ 12 \text { jar } & \\ 13 \text { mate } \\ 14 \text { mirror } \\ 15 \text { opera } \\ 16 \text { pond } \\ 17 \text { province } \\ 18 \text { slice }\end{array}$

(B)

1 annual

2 concealed 計画

3 definite 出合う

4 discharge 手のひら

5 encounter 年 1 回の

6 illustrate

7 marble はっきりと確定した

8 mental 野生の

9 palm 例証する

10 prevail わくわくする感じ

11 previous

12 restore

13 ridge

14 savage

15 scheme

16 statue

17 thrill

18 toss 


\section{Appendix 3}

All the 72 Items in the Increasing Order of IF Differences

\begin{tabular}{|c|c|c|c|c|c|}
\hline No & Item ID* & Items & $63 \mathrm{IF}$ & $189 \mathrm{IF}$ & Differences \\
\hline 1 & 2K12 & pride & 0.982 & 0.991 & -0.009 \\
\hline 2 & $2 \mathrm{~K} 07$ & invite & 0.982 & 0.982 & 0.000 \\
\hline 3 & $3 \mathrm{~K} 02$ & angel & 1.000 & 1.000 & 0.000 \\
\hline 4 & $5 \mathrm{~K} 15$ & hug & 0.991 & 0.991 & 0.000 \\
\hline 5 & $2 \mathrm{~K} 18$ & birth & 1.000 & 0.991 & 0.009 \\
\hline 6 & $5 \mathrm{~K} 03$ & apron & 0.991 & 0.982 & 0.009 \\
\hline 7 & $2 \mathrm{~K} 13$ & temperature & 0.982 & 0.965 & 0.018 \\
\hline 8 & $2 \mathrm{~K} 03$ & total & 1.000 & 0.982 & 0.018 \\
\hline 9 & 2K17 & victory & 1.000 & 0.982 & 0.018 \\
\hline 10 & 3K09 & slice & 0.991 & 0.956 & 0.035 \\
\hline 11 & $5 \mathrm{~K} 12$ & skip & 1.000 & 0.965 & 0.035 \\
\hline 12 & $2 \mathrm{~K} 04$ & manufacture & 0.965 & 0.921 & 0.044 \\
\hline 13 & AWL02 & episode & 0.886 & 0.842 & 0.044 \\
\hline 14 & $2 \mathrm{~K} 08$ & hide & 0.921 & 0.868 & 0.053 \\
\hline 15 & 2K15 & salary & 0.991 & 0.939 & 0.053 \\
\hline 16 & 2K11 & debt & 0.693 & 0.640 & 0.053 \\
\hline 17 & 2K16 & sport & 0.991 & 0.930 & 0.061 \\
\hline 18 & $5 \mathrm{~K} 13$ & blend & 0.912 & 0.842 & 0.070 \\
\hline 19 & 3K02 & herd & 0.237 & 0.158 & 0.079 \\
\hline 20 & AWL17 & minimum & 0.868 & 0.789 & 0.079 \\
\hline 21 & $3 K 05$ & charity & 0.974 & 0.886 & 0.088 \\
\hline 22 & $2 \mathrm{~K} 02$ & private & 0.982 & 0.886 & 0.096 \\
\hline 23 & $3 \mathrm{~K} 10$ & palm & 0.596 & 0.500 & 0.096 \\
\hline 24 & AWL13 & restrict & 0.386 & 0.283 & 0.103 \\
\hline 25 & $2 \mathrm{~K} 06$ & melt & 0.930 & 0.825 & 0.105 \\
\hline 26 & 3K15 & toss & 0.956 & 0.851 & 0.105 \\
\hline 27 & $5 \mathrm{~K} 18$ & wholesome & 0.114 & 0.009 & 0.105 \\
\hline 28 & AWL16 & indigenous & 0.211 & 0.105 & 0.105 \\
\hline 29 & AWL15 & assume & 0.456 & 0.342 & 0.114 \\
\hline 30 & 3K08 & darling & 0.939 & 0.825 & 0.114 \\
\hline 31 & $2 \mathrm{~K} 05$ & elect & 0.956 & 0.833 & 0.123 \\
\hline 32 & AWL08 & discourse & 0.289 & 0.167 & 0.123 \\
\hline 33 & $2 \mathrm{~K} 10$ & roar & 0.456 & 0.325 & 0.132 \\
\hline 34 & 3K04 & bench & 1.000 & 0.868 & 0.132 \\
\hline 35 & $3 \mathrm{~K} 12$ & thrill & 0.833 & 0.702 & 0.132 \\
\hline 36 & $3 \mathrm{~K} 14$ & encounter & 0.763 & 0.632 & 0.132 \\
\hline 37 & $5 K 09$ & revenue & 0.404 & 0.265 & 0.138 \\
\hline 38 & 2K14 & flesh & 0.412 & 0.272 & 0.140 \\
\hline 39 & AWL05 & prestige & 0.254 & 0.105 & 0.149 \\
\hline 40 & $5 K 10$ & precede & 0.439 & 0.283 & 0.155 \\
\hline 41 & $5 K 08$ & apparatus & 0.254 & 0.097 & 0.157 \\
\hline 42 & $2 \mathrm{~K} 01$ & original & 0.833 & 0.675 & 0.158 \\
\hline 43 & $3 \mathrm{~K} 16$ & annual & 0.825 & 0.667 & 0.158 \\
\hline
\end{tabular}


Appendix 3 (Continued)

\begin{tabular}{lllccc}
\hline No & Item ID* & Items & $63 \mathrm{IF}$ & 18 9 IF & Differences \\
\hline 44 & AWL14 & transform & 0.868 & 0.702 & 0.167 \\
45 & $5 \mathrm{~K} 11$ & collapse & 0.465 & 0.289 & 0.175 \\
46 & $5 \mathrm{~K} 17$ & fragrant & 0.789 & 0.614 & 0.175 \\
47 & AWL18 & anonymous & 0.412 & 0.237 & 0.175 \\
48 & $5 \mathrm{~K} 04$ & trumpet & 0.763 & 0.584 & 0.179 \\
49 & 3K13 & illustrate & 0.474 & 0.289 & 0.184 \\
50 & 3K07 & echo & 0.912 & 0.719 & 0.193 \\
51 & AWL01 & affluence & 0.263 & 0.070 & 0.193 \\
52 & 3K18 & definite & 0.588 & 0.395 & 0.193 \\
53 & 3K03 & administration & 0.816 & 0.605 & 0.211 \\
54 & AWL03 & innovation & 0.860 & 0.640 & 0.219 \\
55 & $5 K 06$ & sermon & 0.325 & 0.096 & 0.228 \\
56 & AWL09 & hypothesis & 0.474 & 0.228 & 0.246 \\
57 & $5 \mathrm{~K} 14$ & devise & 0.447 & 0.202 & 0.246 \\
58 & AWL06 & oscillation & 0.298 & 0.035 & 0.263 \\
59 & 3K11 & scheme & 0.474 & 0.202 & 0.272 \\
60 & $5 K 07$ & compliment & 0.430 & 0.149 & 0.281 \\
61 & $5 K 02$ & mess & 0.456 & 0.168 & 0.288 \\
62 & AWL11 & expel & 0.421 & 0.132 & 0.289 \\
63 & $5 K 16$ & gloomy & 0.623 & 0.333 & 0.289 \\
64 & $5 K 01$ & phase & 0.474 & 0.177 & 0.297 \\
65 & 3K17 & savage & 0.649 & 0.351 & 0.298 \\
66 & AWL07 & configuration & 0.342 & 0.044 & 0.298 \\
67 & AWL10 & supplement & 0.781 & 0.474 & 0.307 \\
68 & 3K06 & province & 0.605 & 0.283 & 0.322 \\
69 & AWL12 & deprive & 0.719 & 0.386 & 0.333 \\
70 & 2K09 & spoil & 0.877 & 0.491 & 0.386 \\
71 & AWL04 & deficiency & 0.553 & 0.140 & 0.412 \\
72 & $5 K 05$ & stool & 0.658 & 0.237 & 0.421 \\
\hline
\end{tabular}

Note: Item ID* consists of a combination of a word frequency level and a twodigit number (from 01 to 18) which corresponds to the appearing order of a definition within a word-frequency level in the original VLT. 